\title{
Prospects of Oil and Gas Production of Sedimentary Complexes under the Basalts of Deccan Plateau (India)
}

\author{
V.S. Staroseltsev, K.V. Staroseltsev \\ Russia, Novosibirsk, Siberian Research Institute of Geology, Geophysics and Mineral Resources (SNIIGGiMS) \\ *Corresponding Author: V.S. Staroseltsev, Russia, Novosibirsk, Siberian Research Institute of Geology, \\ Geophysics and Mineral Resources (SNIIGGiMS)
}

\begin{abstract}
Basaltic covers are developed on the Indian platform on the area of 500 thousand $\mathrm{km} 2$. The most extensive basalt plateau forms the Deccan tableland. In contrast to the basaltic plateaus of Eastern Siberia, South America and Africa, the Deccan depression did not experience regional intensive subsidence before the appearance of trap magmatism, but narrow deep aulacogens were formed from the end of the Carboniferous to the beginning of the Cretaceous. The largest of them are connected with the Narmada-Son lineament and the Bombay coast, which in essence pre-determine the location of the most oil and gas - promising zones connected by the basaltic complex of Hindustan.
\end{abstract}

Keywords: basaltic covers, trap magmatism, Deccan plateau, troughs and depressions, aulacogens, Gondwana series, lineament

\section{INTRODUCTION}

The basaltic cover complex is distributed on the Indian platform on the territory of the western coast of India, Katiavar, Kacha, Central provinces and partly the Deccan plateau with a total area of more than 500 thousand $\mathrm{km}^{2}$. Unlike the negative structures associated with the basaltic plateaus of South America and Africa, the Deccan depression has not experienced regional intensive diving before the appearance of trap magmatism, on the contrary, since the Cambrian, according to M.S. Krishnan and M.V.Muratov, most of its territory remained elevated.

\section{RESULTS AND DISCUSSION}

The most extensive basaltic plateau in India is confined to the Deccan highland, which corresponds tectonically to the trap depression of the same name (Fig. 1).

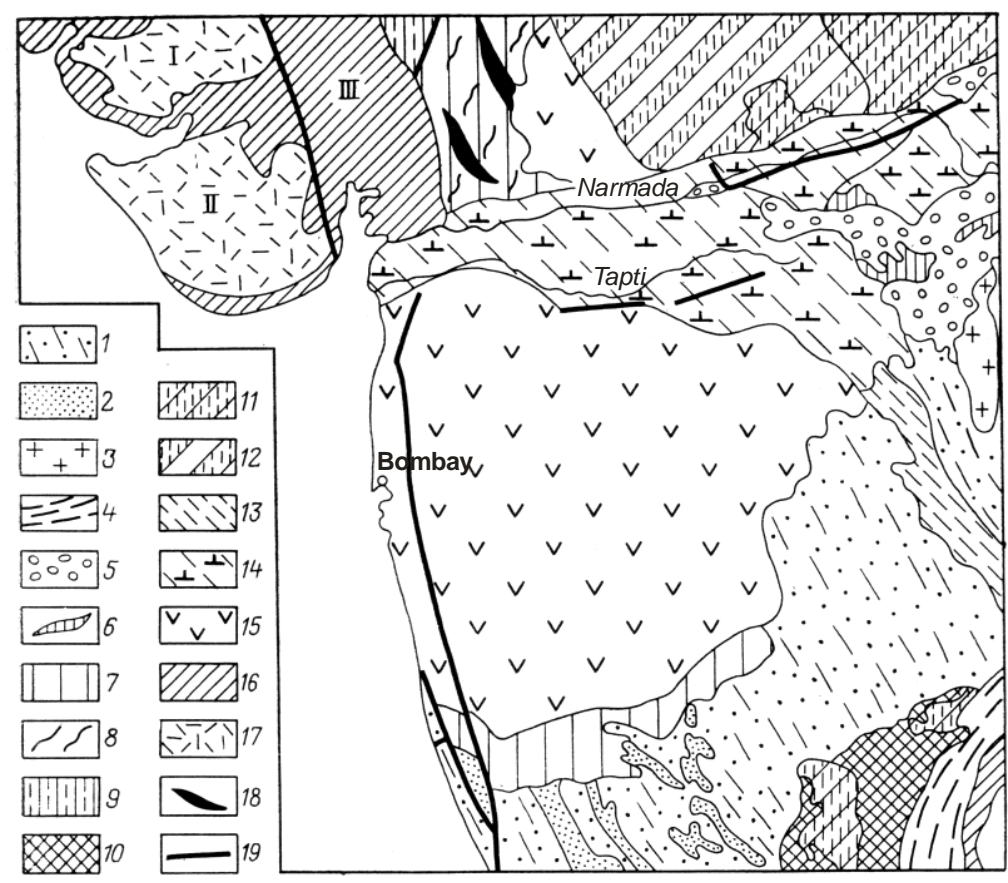

Fig1. Fragment of the tectonic scheme of the Indian platform (according to M.V. Muratov, 1964). 

(India)

Folding systems of the basement: 1-Darvar, 2-synclines in the Darvar system, consisting of crystalline schists, 3 - post- Darvar massifs of granitoids, 4 - East Gat, 5 - Satpur, 6 - anticlinoria in the Satpur system, 7 - Delhi, 8 - anticlinoria in Delhi system, 9 - synclinal structures filled with the Delhi series. Structural elements of the platform cover: 10 - depressions filled with Cuddapakh deposits, 11 depressions filled with Vindian deposits, 12 - part of the Vindi depression under the cover of the trap, 13 - Gondwana graben-shaped depressions, 14 - Gondwana depressions, assumed under the trap cover, 15 - Deccan depressions, filled with thick covers of traps, 16 - pericratonic basins filled with Jurassic, Cretaceous, Paleogene and Neogene deposits, 17 - anteclise with Mesozoic-Cenozoic cover, 18 - major anticlines, 19 - the main faults. Anteclise: I - Kach, II - Kathiavar, III - Cambay graben

Only in the Middle Carboniferous time within it systems of large ruptures began to develop, which were accompanied by the formation of narrow deep troughs of the aulacogen type from the end of the Carboniferous to the beginning of the Cretaceous (Fig. 2), filled with continental sediments of the Gondwana series.

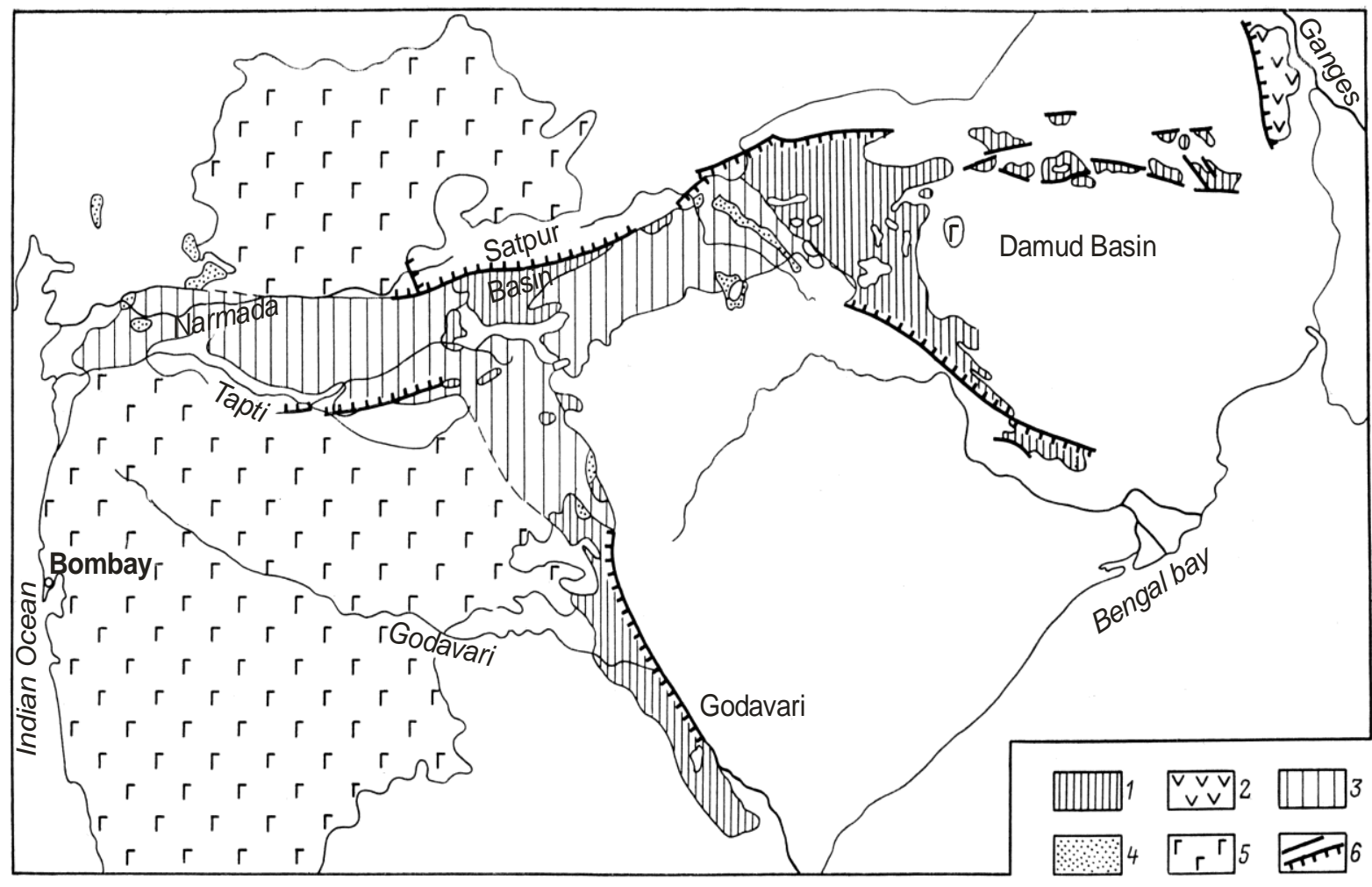

Fig2. The scheme of location of the system of Gondwana aulacogens (according to M.V. Muratov, 1964)

1 - graben-shaped depressions, filled with sediments of the Gondwana series; 2 - Rajmahal depression, filled with the Upper Gondwana series with thick effusives; 3 - Gondwana depressions under the cover of traps; 4 - outcrops of the Upper Cretaceous marine sediments; 5 - Deccan's depression, filled with thick covers of traps; 6 - the main faults

At the base of the Gondwana series (according to M.S. Krishnan), in many areas there is a horizon of boulder glacial and water-glacial deposits with a thickness of 15-30 m, above which clay shales and sandstones with a total thickness of 150-240 m lie. They are also mainly of glacial origin. These deposits are unconformably covered by the thickness of white to yellowish brown sandstones and gravelites, sometimes conglomerates with coal layers and interbeds of shales with a total thickness of up to $700 \mathrm{~m}$.

Above the section there are follows a predominately clay shales with interlayers of sandstones ("empty layers") up to $600 \mathrm{~m}$ thick. Then a thick layer of fine-grained sandstones and clay shales with coal layers whose thickness sometimes exceeds $900 \mathrm{~m}$ is again fixed. On the eroded surface of this layer, and on separate areas - and older deposits, clay shales and sandstones lie, often with crossbedding, which do not contain either coal beds or carbonaceous material. Their total thickness reaches 450-600 m. These deposits terminate the section of the lower part of the Gondwana series. 
The upper part of the Gondwana series begins with a lenticular thickness of reddish coarse-grained sandstones with rare interlayers of red, sometimes hematite, clays and strata of dense ferruginous rocks. The thickness of this layer reaches $750 \mathrm{~m}$. The variegated clays with interlayers of white and yellow, often calcareous sandstones with a total thickness of up to $350 \mathrm{~m}$ are located above. In the eastern regions of India (the right bank of the lower Ganges river), the higher part of the section is represented by a series of basalt covers with interlayers of carbonaceous argillaceous shales and refractory clays. Their total thickness is $450-600 \mathrm{~m}$, and the sedimentary interlayers are only $30 \mathrm{~m}$. To the west, sandstones and grs of light and brown color with subordinate intercalations of clays and separate layers of limestones overlap inconsistently on the thickness of red clays. The thickness of this terrigenous complex is $600 \mathrm{~m}$. A pack of light-colored clays and massive loose sandstones with rare thin interlayers of coal is above not everywhere, the total thickness of a pack usually does not exceed the first hundreds of meters. In some areas this pack is covered with Deccan basalts. However, in the extreme west (northern coast of the Kach Bay) under the basalts, besides the described ones, a thick (up to $900 \mathrm{~m}$ ) thickness of marine sandstones and clay shales is developed.

The completeness of the Gondwana section is not the same in various depressions. Significant changes and its composition are recorded, not only when comparing different depressions, but also within each of them. Particularly significant fluctuations in the thickness of both the entire thickness of the Gondwana sediments as a whole and its individual stratigraphic elements. These changes (according to M.S. Krishnan and M.V. Muratov) are largely predetermined, on the one hand, by the isolation of the development of the Gondwana depressions in the conditions of the continental regime, on the other, by certain features of their structure. All of them are essentially asymmetric graben-like troughs. Restrictive fractures, as S. Fox showed in the 1930s, are mainly faults with active consedimentary development. A significant role was played by many of these faults and later, during the formation of the Deccan trap complex, often retaining its mobility up to the present time [1].

Gondwana graben-like troughs and depressions form several linearly elongated intersecting systems in the body of the Hindostan platform (see Figure 2). Two of them are partially located within the territory of the modern distribution of the Deccan basalts: the western half of the Satpuri-Damodar system and the northwestern end of the Godavari depression. Their joint (according to M.V. Muratov) occurs, probably, near the sources of the Tapti river under the thick of basalts. The most extensive is the Satpuri-Damodar system. It is traced in the latitudinal direction, gradually deeper from the lower current of the Ganges river in the east across the upper reaches of the Son river along the whole Narmada river to the Cambay bay in the west. The large lineament Narmada-Son, limiting this system from the north, can be traced to the island of Madagascar [2].

Graben-like trough, adjacent to the south to the Narmada-Son lineament, was characterized (according to M.S. Krishnan) active sedimentation and tectogenesis for a long time. The thickness of the deposits of the Gondwana series accumulated in its eastern part (the Satpur basin, see Fig. 2) reaches $2 \mathrm{~km}$. We can expect an increase in the thickness of the sedimentary rocks underlying the Deccan basalts, since this trough was most likely opened to the sea during of the entire Cretaceous period [1]. The tectonic activity of the Narmada-Son trough is evidenced by a sharp increase in the number of the trap dikes within its limits, which have a predominantly sublatitudinal orientation. In addition, as shown by P.C. Pal and V.L.S. Bhimasankaram (1976), the Deccan basalts of the opposite slopes of the valley of the Narmada river have a different age. Repeatedly, tectonic movements occurred in this zone in the late Tertiary, Pliocene and even the present, as, for example, the 1970 earthquake in the Broca region with a magnitude of 5.4 points indicates [1]. Significant activity of vertical movements in the valley of the Narmada river is also expressed in the changes (from 30 to $300 \mathrm{~m}$ ) of the quaternary deposits forming it.

The Godavari system of graben-like depressions and troughs is confined to the northeastern part of the basaltic field of the Deccan plateau. The faults that limit these depressions from the east are characterized by steep slopes of the shifters and large amplitudes, and the western bound is represented by a stepped system of gently sloping low-amplitude fractures [1]. The width of the graben-like structures of Godavari reaches $50-80 \mathrm{~km}$. In the most submerged zone, the thickness of sedimentary rocks, according to seismic data, is about $5 \mathrm{~km}$, of which the lower $1.5 \mathrm{~km}$ are roughly of late Precambrian (Kuddapakh) age. The same thickness is reached by the sediments of the lower part of the Gondwana series. 

(India)

In addition to depressions and troughs filled with Gondwana sediments, according to geophysical data, the continuation of the small Precambrian (Delhi) basins of Kaladgii and Bhayma located near the southern edge of the basaltic plateau is planned under the basaltic thickness of the Deccan plateau [1]. In the same paper, a map is presented, in which three small isolated diving zones are presumably contoured in the more northern regions of the Deccan plateau. The largest of them, reaching a length of $250 \mathrm{~km}$ with a width of about $100 \mathrm{~km}$, adjoins from the east to the major fault (see Figure 1) and is extended from the latitude of Bombay in the south-southeast direction; two other zones located to the north and east of the first have significantly smaller dimensions: $40 \square \square \square 90$ and $45 \square \square 65 \mathrm{~km}$. No information is given on the amplitudes of downwarping and the nature of the fulfillment of these zones in this work.

To the north of the middle course of the river. Narmada under the cover of the Deccan basalts, in addition to the ancient folded and crystalline complexes, on the area of about 80 thousand $\mathrm{km}^{2}$ there is a thick (up to $1 \mathrm{~km}$ and more) rock mass of Precambrian (Vindian) sandstones and limestones filling the Vindian depression (according to M.S. Krishnan and M. V. Muratov). The flanges of the latter are often confined to faults, near which the Vindian rocks acquire a steep dip, which gives the depression a graben-like appearance.

These are the main features of the structure of the territory on which, according to N.A. Vemban (1950), M.S. Krishnan, B.R.N. Sukhesuala and A. Poldervaart (B. R. N. Sukhesuala and A. Poldervaart, 1958), basalt covers began to form at the end of the Cretaceous. According to the latest data, the age of the Deccan basalts varies from 60-65 to 40-45 million years [1,3]. The volcanogenic stratum reaches (according to N.A. Vemban and M.S. Krishnan) the maximum total thickness exceeding $2 \mathrm{~km}$, in the area of the Bombay coast, from which it decreases to $150 \mathrm{~m}$ on the eastern edge of the basalt field, $60 \mathrm{~m}$ on the southern and 30-60 $\mathrm{m}$ in the northwest. The base of volcanogenic formations, according to seismic soundings [1], lies at absolute elevations from -746 to $+530 \mathrm{~m}$. The lowest absolute marks $(-262,-340,-642$ and $-746 \mathrm{~m})$ are recorded within a wide zone of the northeast directions between the Bombay coast and the valley of the rivers Tapti and Narmada. On the sides of this zone, the base of the Deccan basalts experiences a differentiated rise to 90-396 m in the south, 202-405 $\mathrm{m}$ in the east and 70-170 $\mathrm{m}$ in the north within the Vindian depression. A rare network of points in which absolute marks were determined does not allow us to draw definite conclusions about the relief of the base of the basalts, but presumably it can be assumed that the latter does not form within the limits of the Deccan plateau a deep detached depression of the syneclise type.

The most important tectonic elements of the territory of the present-day distribution of the Deccan basalts are the two regional zones of faults that are almost perpendicular to each other. One of them, elongated in the sublatitudinal direction by $1500 \mathrm{~km}$ [1], is widely known as the Narmada-Son lineament. It has an ancient pre-trap origin and was described above. It is only necessary to add that the features of the modern structure of this zone and the adjacent territories allowed it to be considered similar to the rifts of East Africa, which are associated with the large dome-shaped uplifts of the Africa-Arabian platform.

Other fault zone has submeridional orientation and traced from the Cambay graben to the south more than $500 \mathrm{~km}$ [1]. Within this zone, the volcanogenic strata, with a thickness of more than $2 \mathrm{~km}$, forming the western part of the Deccan plateau, are inclined and lowered towards the sea. In the coastal region to the north-west from the city of Bombay, the Deccan basalts are already submerged to $1,760 \mathrm{~m}$ and covered by sedimentary rocks of the Oligocene, Miocene and Pliocene, $70 \%$ of which are massive limestones [1]. To the north, on the territory of the Cambey graben, the trap complex is submerged under the Cenozoic deposits to a depth of $2-3 \mathrm{~km}$, which is established from the data of drilling oil wells. A significant increase in the thickness of volcanogenic formations as they approach the described zone and intense post-trap subsidence allow us to assume that before the outflow of basalts, a sufficiently deep trough filled with sediments of the Gondwana series could have been associated with this zone.

Both described fault zones form an orthogonal system, to the south-eastern sector of which the main basaltic plateau of the Deccan tableland is confined. On the large parts of the territory of this plateau, as well as the mountain structures of the Vindi Basin, the effusive rocks are represented exclusively by basalts. However, along the western coast of Hindustan (the Bombay region), in the valley of the Narmada river and its continuation on the Kathiyavar Peninsula (see Figure 1), in addition to normal basalts, igneous rocks of ultrabasic, middle, alkaline and acidic composition in volcanic, plutonic and 

(India)

hypabyssal facies are widely developed, which was repeatedly emphasized in the published works of the 1950s-1980s [4]. Herewith among the acidic and alkaline differences, there are microgranits, granophyry, rhyolite, felsite, rhyodacite, dacite, trachyte, ignimbrite and obsidian, typical of magmatic formations within the rift and near-fault zones of East and North Africa.

\section{THE CONCLUSION}

Thus, there is a similarity of the Deccan volcanites covering a significant part of the ancient Indian platform with the volcanic complexes of the rifting regions on the Africa-Arabian platform not only in tectonic features [1] but also in the composition of their constituent rocks. The main differences in the territory of the manifestation of trap magmatism on the Indian platform are a much smaller rise in the earlier stages of development and limited lateral distribution of acid effusives. The bed of the Deccan basalts has been shown to have a complex structure. In its boundaries, along with the long-elevated blocks, a number of submerged zones filled with sediments are marked. In this respect, the volcanic stratum of the Deccan takes an intermediate position between the traps that covered the platform areas of sustainable regional subsidence and the traps on the major uplifts of the platform basement complicated by rifting processes. It is not excluded that these particular features of the structure of the Deccan basalts bed largely predetermined the constancy of the composition of volcanogenic formations outside the rift zones of the Indian platform. The spread of acidic effusives with high viscosity over considerable distances (for example, the width of the Kenyan rift volcanic belt reaches $550 \mathrm{~km} \mathrm{[5])} \mathrm{is} \mathrm{possible} \mathrm{if} \mathrm{there} \mathrm{is} \mathrm{a} \mathrm{sufficiently} \mathrm{dense} \mathrm{network} \mathrm{of} \mathrm{lava} \mathrm{feeding} \mathrm{channels.} \mathrm{Apparently,}$ in the tectonic conditions of the western part of the platform, such channels could exist only in the zones of regional faults of the Bombay coast and the Narmada-Son lineament which in essence predetermine the location of the most oil and gas - promising zones connected by the basaltic complex of Hindustan. Indirect proof of this assumption is the almost complete absence of vertical or horizontal displacements along the ruptures of basaltic covers developed aside from these regional zones [3].

\section{REFERENCES}

[1] Kailasam L.N. Platean uplift in Peninsula India, Tectonophysics, 1979, vol.61, N 1-3, pp. 243-269.

[2] Crawford A.R. Narmada-Son Lineament of India traced into Madagascar, J. Geol. Soc. India, 1978, vol.19, pp. 144-153.

[3] Sahasrabudhe G.S., Desmukh S.S., Roy S.K. et al. Deccan basalts flows exposed along Poladpur Mahabaleshwar and Amboli - Ghat section in Western Ghat. India. A Geological study, Rec. Geol. Srv. India, 1977, vol. 108, N 2, pp. 69-80.

[4] Krishnamurty P. Cox K.G. A potassium - rich alkaline suite from the Deccan Traps, Rajpipla, India, Contributions Mineral. and Petrol., 1980, vol. 73, N 2, pp. 179-189.

[5] Williams L.A. The volcanological development of the Kenia rift, Proc. NATO Adv. Study Inst. Paleorift. Syst., Emphasis Permian Oslo rift, Oslo, 1977, vol. 1. Petrol. And Geochem. Contin. Rifts, pp. 101-121.

\section{AUTHORS' BIOGRAPHY}

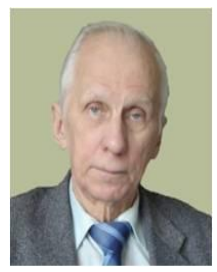

Valery Stepanovich Staroseltsev, was born in 1936 in Rostov-on-Don (Russia), Doctor of Geological and Mineralogical Sciences (Dr), Professor (Prof.), full member of the Russian Academy of Natural Sciences and MAMR, scientific leader of the Siberian Research Institute of Geology, Geophysics and Mineral Resources (Novosibirsk, Russia) in regional and oil and gas geology.

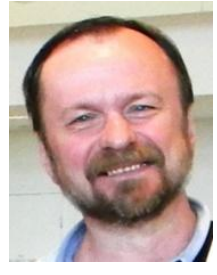

Kirill Valeryevich Staroseltsev, was born in 1960 in Rostov-on-Don (Russia), candidate of geological and mineralogical sciences $(\mathrm{PhD})$, senior expert of the Siberian Research Institute of Geology, Geophysics and Mineral Resources (Novosibirsk, Russia).

Citation: V.S. Staroseltsev, \& K.V. Staroseltsev, (2017). Prospects of Oil and Gas Production of Sedimentary Complexes under the Basalts of Deccan Plateau (India), International Journal of Petroleum and Petrochemical Engineering (IJPPE), 3(4), pp.97-101, DOI: http://dx.doi.org/10.20431/2454-7980.0304010

Copyright: (C) 2017 V.S. Staroseltsev, \& K.V. Staroseltsev. This is an open-access article distributed under the terms of the Creative Commons Attribution License, which permits unrestricted use, distribution, and reproduction in any medium, provided the original author and source are credited 